doi:10.5128/ERYa17.08

\title{
SOTSIOPRAGMAATILINE SISSEVAADE KOODIVAHETUSELE: NÄITEID ROOTSIEESTI TEISMELISTE KEELEST
}

\section{Mari-Liis Korkus}

\begin{abstract}
Ülevaade. Artiklis analüüsitakse koodivahetuse funktsioone viie rootsieesti noore suulise keelekasutuse näitel. Vaatluse all on eelkõige eesti ja rootsi, osalt ka inglise keele koosmõju. Koodivahetuse näidete põhjal uuritakse, miks toimuvad keeltevahelised üleminekud ning milliseid ülesandeid täidab vaadeldav nähtus suhtlustegevuses. Uurimisandmed on kogutud vestlusringide vormis, kus keelejuhid suhtlesid omavahel mängulistes ja arutlevates situatsioonides. Kogutud ainestikus kodeeriti kokku kuus funktsiooni: semantiline seos, kvaasitõlge, sõnaotsing, keelemäng, voorudeülene keeleharmoonia ja ekspressiivsus. Tulemused näitasid, et kõige enam oli noorte koodivahetuses esindatud semantiline seostamine ja kvaasitõlge.*
\end{abstract}

Võtmesõnad: mitmekeelsus, koodivahetus, sõnavara, eesti keel, rootsi keel, inglise keel

\section{Sissejuhatus}

Eesti keeleteaduses on koodivahetust uuritud eesti-vene, eesti-soome, eesti-inglise ja eesti-läti keelepaaride näitel. Uurimisküsimused on uurijate lõikes varieerunud, kuid eelkõige on uuritud koodivahetuse grammatikat, st kuidas toimub ühe keele elementide sisestamine ja integreerimine teise keelde (vt Joenurma 2016, Vihman 2018, Verschik 2019). Lisaks on uuritud koodivahetuse funktsioone: mis põhjusel vahetab kõneleja vestluses koodi (keelt) ning milliseid ülesandeid selline koodivahetus täidab (vt Zabrodskaja 2006, Hein 2014, Praakli 2016). Käesoleva töö fookuses on koodivahetuse funktsioonid rootsieesti teismeliste suulises keelekasutuses. Artikkel põhineb autori magistritööl (Korkus 2020).

Tänapäeva eestlaskond Rootsis põlvneb suuresti II maailmasõja aegsest pagulaskonnast, kuigi eestlasi elas Rootsis varemgi (esimesed ametlikud andmed pärinevad 1920. aasta rahvaloendusest). 1950. aastal registreeriti Rootsi rahvaloendusel, et sõja ajal jõudis ning jäi Rootsi püsivalt elama ligi 25000 Eesti päritolu isikut.

* Uuringut on toetanud Tartu Ülikooli Sihtasutuse Karine ja Martin Koobase stipendium. 
Järgmine suurem ümberasumine algas 1980. aastate lõpus, mil Nõukogude Liidu lagunemise ajal suundusid eestlased Rootsi abielu, töö või õpingute tõttu, kuid täpne statistika selle perioodi kohta puudub. (Raag 2010) Alates 1990. aastatest toimub ränne eelkõige majanduslikel põhjustel (Kumer-Haukanõmm, Telve 2017). 21. sajandi esimesel kümnendil, mil Eesti astus Euroopa Liitu, kasvas rootsieestlaste arv peamiselt töö- ja õpirände tulemusel ligi 2000 võrra. Praegu elab Rootsis Rootsi statistikaameti andmetel ${ }^{1}$ eestlasi (st kas Eestis sündinud või Eesti kodakondsusega) ligi 10 ooo. Paljud sisserännanud eestlased on jäänud Rootsi elama alaliselt. (SCB, Raag 2010)

Teiste väljaspool Eestit elavate eesti keele kõnelejate kogukondadega võrreldes on rootsieestlaste keelt ilmselt kõige enam uuritud (Raag 2010). Üldiselt keskenduvad uuringud täiskasvanute keelekasutusele, vähemal määral lastele (nt Kiviloog 1983). Siinne uuring keskendub kahe keele - eesti ja rootsi - kasutusele rootsieesti noorte suulistes vestlustes. Inglise keele kasutust mitmekeelses suhtluses käsitletakse üksnes siis, kui see on suhtluses toimuva selgitamise osas tähenduslik. Artiklis keskendutakse sotsiopragmaatilisele analüüsile ning püütakse selgitada, milliseid funktsioone täidab uuritavate noorte vestlustes ilmnev koodivahetus. Varem on küll kirjeldatud keelekontaktidest johtuvat varieeruvust ja muutusi rootsieesti noorte keeles, kuid nendes on uuritud koodivahetuse grammatikat (vt ka osa 3). Siinne artikkel vaatleb koodivahetuse funktsioone viie noore vahelises suhtluses. Sellest vaatenurgast on koodivahetust Rootsi eestikeelsete kogukondade näitel uuritud vähe.

Järgmises osas antakse ülevaade varasematest koodivahetust ja ka rootsieestlaste keelt käsitlevatest uuringutest. Kolmandas osas kirjeldatakse käesoleva uurimuse metoodikat ning keelejuhte. Neljandas osas tutvustatakse uurimistulemusi, sh andmestikus esinenud koodivahetuse sotsiopragmaatilisi funktsioone. Viiendana järgneb kokkuvõte.

\section{Uuringu taust}

\subsection{Koodivahetuse sotsiopragmaatilised funktsioonid}

Suhtlejatevahelised kontaktid võivad kõneleja keelekasutust mõjutada nii grammatika kui leksika osas. Kui suhtlejate keelelisse repertuaari kuulub eri keeli, siis leiavad aset keelekontaktidest johtuvad muutused (vt Thomason, Kaufman 1991, Thomason 2001, Verschik 2010). Koodivahetus (ingl code-switching) on üks keelekontaktiga kaasnevaid nähtusi ja mitmekeelse kõne tunnusjooni. Kõige üldisemas tähenduses tähistab koodivahetus situatsiooni, kus vaheldumisi kasutatakse vestluses kahte või enamat keelt (või murret) (Verschik 2004, Gardner-Chloros 2005).

Koodivahetuse uuringutes võib eristada kahte peamist suunda. Grammatilise lähenemise esindajaid huvitab eeskätt, milline on koodivahetuse morfoloogia ja süntaks (nt Myers-Scotton 1997, Johanson 2002). Sotsiopragmaatilise lähenemise esindajaid huvitab, millist funktsiooni koodivahetus täidab ning milline on kõnelejate omavaheline suhe ja laiem suhtluskontekst.

1421 Statistika on ebatäpne, sest Rootsi statistikaamet registreerib kõik Rootsis sündinud isikud rootslaste alla. Mitterootslaste sekka arvestatakse vaid need, kes on sündinud väljaspool Rootsit või on teise riigi kodakondsusega (Raag 2010). 
Koodivahetuse funktsioone on kirjeldanud näiteks François Grosjean (1982), John Joseph Gumperz (1982), Peter Auer (1995), René Appel ja Pieter Muysken (2005) ning Carol Myers-Scotton (2006). Tulenevalt erinevast uurimisainestikust ja erinevast tõlgendamisest on funktsioonide liigendus eri autoritel mõneti varieeruv. Allpool on välja toodud, millistes aspektides ilmneb nende käsitlustes sarnasusi (vt ka Zabrodskaja 2006: 233).

Kasutades keelt, mida kõneleb vaid osa vestluskaaslastest, saab kõneleja koodivahetusega viidata, kellele vestluses osalejaist on tema öeldu suunatud. Seda funktsiooni liigendavad autorid erinevalt: Grosjean (1982) nimetab vestluspartneri kaasamist (ingl speaker involvement specification) ja vestlusest välistamist (speaker exclusion) eraldi funktsioonideks, seevastu Auer (1995) paigutab neid osalejaskonna muutuse funktsiooni alla (change of participant constellation). Vestluses osalejatega seotud koodivahetust nimetavad Appel ja Muysken (2005) suunatud (directive) koodivahetuseks. Teise funktsioonina nimetatakse sõnumi rõhutamisega seotud koodivahetust (Auer 1995 järgi reiterations ehk kvaasitõlked, vt ka siin osa 4). Koodivahetus võib funktsioneerida ka sõnumi võimendajana (argument "topper"), et toonitada või täpsustada öeldut (Grosjean 1982).

Aueri (1995) sõnul võib koodivahetus täita keelemängu (language play) funktsiooni, näiteks kasutades mitme keele mõjutusega väljendit, mis keeleliselt mõjub naljakana. Appel ja Muysken kirjeldavad, et keelenaljad täidavad poeetilist (poetic) funktsiooni. Tihti on koodivahetus seotud mingi kindla teemaga ehk see täidab referentsiaalset funktsiooni (referential), näiteks mõnest valdkonnast rääkides eelistatakse kasutada ühte keelt, mis omakorda näitab, et mitmekeelse kõneleja sõnavaraoskus on keeliti erinev. (Appel, Muysken 2005)

Gumperz (1982) leiab, et mitmekeelse kõneleja keeled on tähenduslikud, millest tulenevalt liigitab ta oma semantilises mudelis koodivahetuse situatsiooniliseks ja metafooriliseks. Situatsioonilist koodivahetust tingivad keelevälised faktorid, nt kõnelejad, vestlusteema või suhtlusviis. Metafooriline koodivahetus seevastu tuleneb kõneleja isiklikust otsusest. Koodivahetusega vahendatav sõnum on metafoor, mille mõistmise aluseks on kõneleja ja vestluskaaslas(t)e ühised teadmised.

Appel ja Muysken (2005) näevad seoseid koodivahetuse ja identiteedi väljendamise vahel, nimetades koodivahetust ekspressiivseks (expressive). Mõnes kogukonnas väljendab kõneleja koodivahetuse abil identiteeti, mis võib olla seotud nii üksikisiku kui grupiga. Seda seost kirjeldavad ka Grosjean (1982) ja MyersScotton (2006).

Selgitamaks, kuidas koodivahetamisel väljendub just grupiidentiteet, pakub Gumperz (1982) välja, et kaks keelt paiknevad erinevates suhtlusruumides ning eristatakse "meie-" ja "nende-koodi". Mitmekeelses kogukonnas on vähemuskeel sageli "meie-kood", mida kõnelejad kasutavad mitteformaalses grupisiseses suhtluses. Seevastu "nende-kood" on kogukonna enamuskeel, mida kasutatakse grupiväliselt ja formaalseks suhtluseks. Seesuguse eristamise funktsioonide kohta esineb erinevaid seisukohti. Grosjean (1982) leiab, et vahetuv kood annab edasi mingit kõneleja isiklikku sõnumit. Myers-Scotton (2006) seostab seda eeskätt sooviga väljendada staatust ja võimu, näiteks enamuskeele kasutamisega väljendab vähemuskeele kõneleja lugupidamist oma vestluspartneri suhtes.

Koodivahetusega saab kõneleja anda edasi emotsiooni, näiteks viha või pahameelt (Grosjean 1982). Kõrvutades Grosjeani ja Aueri (1995) käsitlusi, leiab kolm 
sarnast funktsiooni. Esimene on tsiteerimine ehk kellegi öeldu kordamisega kaasnev koodivahetus (reported speech). Teine on seotud kõneleja rolli muutumisega (role shift) - vastavalt olukorrale võib kõneleja keelekasutus muutuda juhul, kui mõne vestluskaaslase positsioon suhtlustegevuses muutub, näiteks kui vestlusega ühineb autoriteetsem kõneleja. Auer (1995) toob välja, et koodivahetus ei pruugi kaasneda mitte üksnes rolli, vaid ka tegevuse muutusega (change of activity). Samuti võidakse koodi vahetada (vestlustes kasutatavate keelte) kommenteerimiseks. Appel ja Muysken (2005) täpsustavad, et metakeele kaudu saab kõneleja näiteks demonstreerida oma paremat keeleoskust ja/või väljendada parema keeleoskusega oma kõrgemat staatust. Sel juhul vahetatakse koodi metalingvistiliseks (metalinguistic) kommenteerimiseks.

Erinevusi leidub käsitlustes veelgi. Grosjean (1982) toob tähelepanekuna välja keelelise käitumise: kõneleja peegeldab oma vestluspartnerit, jätkates teise kõneleja valitud keele kasutamist juhul, kui too oli eelnevas voorus vestluskeelt vahetanud (triggering). Seda võib vaadelda aga koodivaheldumisena (vt Johanson 2002, võimalikke mustreid kirjeldab ka Auer 1995). Teistsugune lähtenurk koodivahetuse kirjeldamisel on Myers-Scottonil (2006), kes ei loetle otseselt funktsioone, vaid eristab kõneleja markeeritud (marked) ja markeerimata (unmarked) valikuid keelekasutuses. Markeerimata valik on ootuspärane, näiteks ingliskeelsetes riikides suhtlevad hispaania-inglise kakskeelsed noored eelduspäraselt vanematega hispaania keeles. Markeeritud valikut pole võimalik ennustada, sest keelekasutus sõltub individuaalsete kõnelejate hoiakutest ja omavahelistest suhetest.

Kokkuvõttes võib koodivahetus olla tingitud erinevatest mõjuritest, mistõttu see, mis funktsiooni üks või teine kood täidab, võib sõltuvalt kõnelejatest, keskkonnast ja konkreetsest olukorrast omakorda varieeruda (vt nt Auer 1999). Rootsieestlaste puhul on koodivahetusel tugevam seos identiteediga just vanema põlvkonna kõnelejate seas, kes sõjapõgenikena kasutasid eesti keelt, hoidmaks seost juurtega (vt 2.2). Nooremate kõnelejate puhul on aga vähe uuritud, kas ja mil määral esineb selget "meie-" ja "nende-koodi” eristamist.

Siinses artiklis võetakse eelmainitud uurijate käsitlustele toetudes vaatluse alla koodivahetuse funktsioonid rootsieesti teismeliste vestluste näitel. Täpsemalt tutvustatakse vestlustes esile tulnud funktsioone artikli neljandas osas.

\subsection{Rootsieesti keel 1970. aastatest tänapäevani}

Rootsi-eesti kakskeelsuse uurimisega hakati tegelema 1970.-1980. aastatel. Peamiselt keskenduti leksikaalsete eripärade kirjeldamisele, eeskätt täiskasvanud keelejuhtide näitel. Raimo Raag on oma väitekirjas (1982) näidanud, et rootsieestlaste keelekasutusele on iseloomulik keelekontaktist johtuv tugev rootsi mõju eesti keelele eelkõige sõnavaras. Sarnaseid tähelepanekuid on teinud Els Oksaar (1970) ning Jaak Kiviloog (1983). Raagi (2010) sõnul kerkis 1950. aastatel sõnapuuduse probleem: Rootsi ühiskonnas võeti kasutusele uued mõisted, mille väljendamiseks puudusid rootsieestlaste keeles sobivad vasted. Seetõttu hakati eestikeelses suhtluses laenama rootsikeelseid uudissõnu. Sarnased sõnavaralüngad tekivad ka tänapäeva noorte keelekasutuses: mõne teema juures ollakse harjunud kasutama just rootsi keelt (vt 4.3 ja 4.4). 
Sajandivahetusel laienes uurijate perspektiiv ja tähelepanu hakati pöörama ka morfoloogiale ja süntaksile. Peep Nemvaltsi (1998) järgi täheldati rootsi mõju näiteks rektsioonis, fraasi- ja sõnajärjes. Kirjeldamaks keelekontaktide mõjusid rootsieesti keeles, kasutasid Aino, Laagus, Birute Klaas ja Mari Allik interferentsi mõistet, mis tähistas "igasugust rootsi keele mõju eesti keelele, täpsustamata, kas on tegemist interferentsiga selle klassikalises tähenduses, transferentsi, koodivahetuse vms." (Laagus jt 2004: 26)

Uurimustes on käsitletud suhtlustegevusi, kus kasutatakse rootsi keelest laenatud pragmaatikat (Keevallik 2006). Huvi on uurijatele pakkunud ka rootsieestlaste enesemääratlus ning selle võrdlemine eesti ja rootsi identiteediga (Valk, Karu 2002, Keevallik 2010). Põlvkondadega on eesti ja rootsi keele suhtelise tähtsuse ning kasutuse osakaal muutunud: tänapäeval oskavad nooremad Rootsis elavad eestlased soravamalt rootsi keelt, vanemad seevastu eesti keelt. Ühise tunnusjoonena on aga välja toodud, et eesti keel Rootsis on arenenud eesti standardkeelest mõneti erinevas suunas. Seetõttu tarvitatakse aeg-ajalt keelendeid, mis võivad erineda Eestis kõneldud keelest. (Raag 2010)

Sarnaselt nimetatud uurimustele (eriti Raag 1982, Keevallik 2006) keskendutakse ka siinses artiklis mitmekeelsele suhtlusele just sõnavara tasandil. Kuigi koodivahetus on sageli seotud sõnavara kasutusharjumustega, võib põhjuseid olla teisigi (vt lähemalt osa 4). Siinse töö fookuses on rootsi keele mõju uurimine, kuid tulenevalt inglise keele suurest levikust 21. sajandil ei saa mööda vaadata ka selle esinemisest koodivahetuses.

\section{Metoodika ja uurimisandmestik}

Uurimus põhines viie teismelise keelejuhi suulistel vestlustel. Valikukriteeriumiteks olid vanus, elukoht ja igapäevane keelekasutus. Vähemalt üks uuritava vanematest pidi kõnelema eesti keelt esimese keelena. Valimi moodustasid keelejuhid vanuses 15-17 eluaastat, kellest kolm olid noormehed ja kaks neiud. Uurimise ajal elasid nad kõik Stockholmis ning õppisid rootsikeelses koolis. Kolm pärinesid kakskeelsest perest (ehk kodus kasutati nii eesti kui rootsi keelt) ning kaks ükskeelsest perest (kodus suheldi ainult eesti keeles). Taustaankeedis andis keelejuht hinnangu, kuidas kodune keel mõjutab tema igapäevast keelekasutust. Kakskeelsest perest pärit keelejuhid vastasid, et kasutavad tavaelus rohkem rootsi keelt, samas ükskeelse pere noored kasutavad enda hinnangul mõlemaid keeli võrdselt. Kõik uuritavad on nn uuema põlvkonna rootsieestlased: nende vanemad kolisid Rootsi 1990. aastatel või hiljem. Üks uuritavatest oli sündinud Eestis ja kolinud perega Rootsi enam kui viis aastat tagasi.

Uuring viidi läbi Stockholmis vestlusringide näol 2019. aasta sügisel. ${ }^{2}$ Vestlusringid toimusid kahes grupis, üks rühm oli kahe- ja teine kolmeliikmeline. Vestlusringi formaat erineb sotsiolingvistilisest intervjuust (vt Becker 2013, Hoffman 2014), kuna vestlusring lubab uurijal kõrvale astuda, et keelejuhid suhtleksid omavahel. Uurija mõju avaldub eelkõige selles, mille üle arutletakse. Ent erinevalt vaatluse meetodist (vt Allwright 2014) olid vestlusringid sisuliselt suunatud: keelejuhid kõnelesid etteantud teemadel, millest osa oli seotud nende igapäevaste harrastustega.

2 Magistritöö uuringu läbiviimine oli kooskõlastatud Tartu Ülikooli inimuuringute eetikakomiteega 
Selline meetodi valik põhines uurija soovil soodustada mitmekeelset suhtlust, kuna oli oht, et tema osalemise korral võiksid uuritavad suhelda teadlikult vaid ühes keeles. Lisaks soodustas see vestluse sujuvust, kuna noored ei pidanud ise välja mõtlema, millest rääkida.

Vestlusring oli kaheosaline: esmalt mängiti sõnamängu, seejärel arutleti etteantud teemade üle (vt joonis 1). Sõnamäng sarnanes olemuselt Aliasega, mängu tarbeks koostas uurija 100 sõnakaarti, mis temaatiliselt olid seotud aruteluteemadega. Siltidel leidus sõnu ja väljendeid, mõnikord ka nimesid kolmes keeles (eesti, rootsi, inglise), näiteks lumehelbeke, lagom ('parajalt'), influencer ('suunamudija'), Astrid Lindgren. Noored pidid kordamööda seletama siltidel olevaid sõnu/väljendeid vestluspartneri(te)le, kes omakorda pidid kirjeldatu ära arvama. Keelekasutuses puudusid piirangud, kirjeldada ning vastust pakkuda võis nii rootsi kui eesti keeles. Tavaliselt suhtlevad uuritavad omavahel eesti keeles ning ka uurija suhtles lindistamisel nendega üksnes eesti keeles. Mängu eesmärk oli tekitada noortes hasarti ning suunata neid vabamale keelekasutusele; keelepõhisus aga aitas kaasa kahe keele aktiveerimisele.

Lühikese pausi järel jätkus vestlusringis suhtlus mõnevõrra vabamas vormis. Uuritavatel paluti vestelda vähemalt ühel etteantud teemadest: noorte tööhõive, tänapäeva keskkonnaprobleemid, sooline võrdõiguslikkus, sport ja tervis, muusika, ESTO ehk üleilmne väliseestlaste kokkutulek, Rootsi ja Eesti elu võrdlus. Teemad valiti selle alusel, et need oleksid eakohased ja aktuaalsed, ning selleks, et suhtlus kulgeks sujuvamalt. Ka arutelus puudusid piirangud kasutatavate keelte suhtes, mistõttu suhtlus toimuski mitmes keeles. Vestlusring salvestati mõlemas grupis kahes jaos. Seejärel paluti noortel täita lühike ankeet. Ankeedis esitatud küsimustega koguti infot iga keelejuhi keelelise tausta, sh koduse keelekeskkonna ja võõrkeeleoskuse kohta.

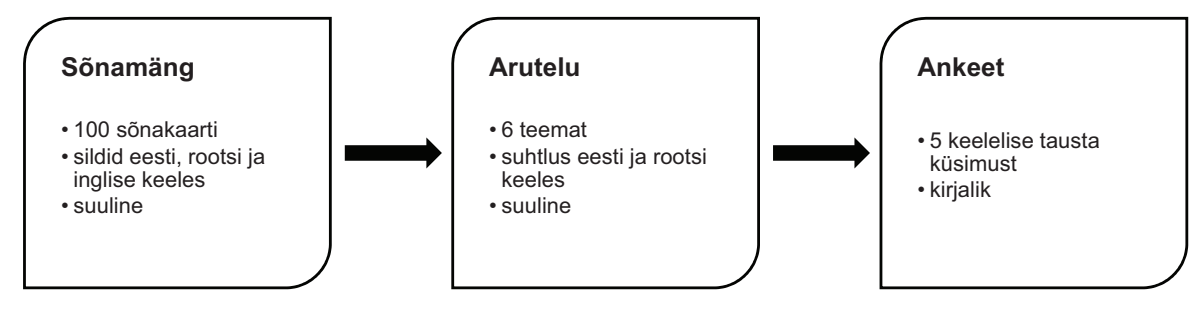

Joonis 1. Vestlusringi ülesehitus

Lindistamise ajal viibis uurija keelejuhtidega samas ruumis ning tegi märkmeid vestlusringi kulgemise kohta. Selline vaatlus võimaldas jälgida, kuivõrd sobilikult oli vestlusring ette valmistatud, arvestades, et eelnevalt polnud võimalik läbi viia pilootkatset. Aeg-ajalt ei teatud sõnamängus kasutatud siltidel olevate sõnade tähendusi (näiteks ee rannarootslased) või eestikeelseid vasteid (näiteks tvåspråkighet 'kakskeelsus'). Tuli ka ette momente, kus uurijat püüti kaasata aruteludesse. Need kohad on analüüsist välja jäetud.

Lindistuste käigus koguti materjali umbes 4 tunni (täpsemalt 248 minuti) mahus. Lindistatud materjali transkribeerimisel kasutas uurija täisautomaatset veebipõhist kõnetuvastust (Alumäe jt 2018) ning annotatsioonitarkvara ELAN (versioon 5.9). Kõnetuvastus sobis kõige paremini eestikeelse kõne tuvastamiseks, 
sest rootsi- ja ingliskeelse kõne puhul pakkus tuvastus häl̈lduspõhiselt sarnaseid eestikeelseid vasteid. Need tuvastused korrigeeriti käsitsi vastava keele ortograafia järgi. Transkribeerimisel tugines uurija osaliselt Tartu Ülikooli suulise eesti keele korpuses (SEKK) kasutatud transkriptsioonireeglitele. Transkriptsioon oli enamasti häl̈lduspõhine, kuid mitte-eestikeelsed lausungi(osa)d kirjutati vastava keele ortograafiale vastavalt ning varustati eestikeelsete tõlgetega.

Lindistatud kõne jagati lausungiteks (kokku 1786), millest 24,6\% (439 lausungit) sisaldas koodivahetust. Suurem osa koodivahetust sisaldavatest lausungitest (63\% ehk 274 lausungit) pärines sõnamängulindistustest (vt joonis 2).

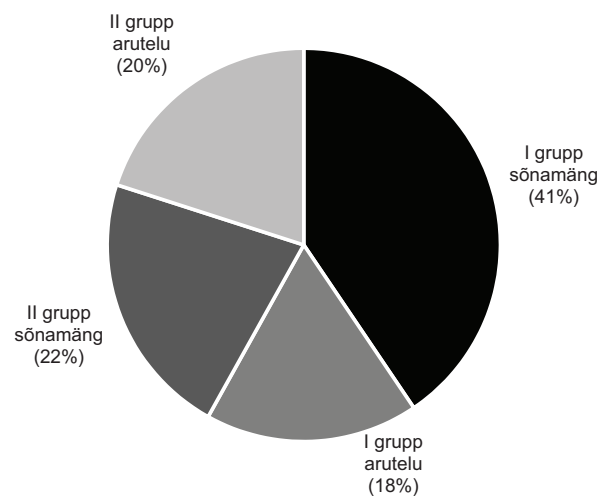

Joonis 2. Koodivahetust sisaldavate lausungite $(n=439)$ jaotus vestlusosade lõikes (I grupp on kahe-, II grupp kolmeliikmeline)

Kõik koodivahetust sisaldavad lausungid viidi eraldi korpusesse, kus uurija märgendas neid ühekaupa. Igas koodivahetust sisaldavas lausungis märgendati järgmised tunnused:

- vestlusosa, milles lausung esines (sõnamäng või arutelu);

- kontekst ehk vestlusteema;

- $\quad k e e l(e d)$ (rootsi, eesti, inglise);

- kõnelejat tähistav osalejakood (KJ1, KJ2, KJ3, KJ4 või KJ5);

- koodivahetuse funktsioonid.

Lausungi esinemiskoht oli nii metodoloogiliselt kui ka analüüsi seisukohast oluline. Märgendus võimaldas võrrelda, kas koodivahetust esines rohkem sõnamängus või arutelus; kontekst (äraarvatav sõna või aruteluteema) aitas aga funktsioone selgemalt piiritleda. Samuti märgendati, milliseid funktsioone täitis vahetuv kood uurija hinnangul. Siinkohal tugineti kontekstile, milles lausung esines, kõnelejatele, vestlusteemale ja ka teoreetilises taustas käsitletud funktsioonidele, kuid hinnangud on siiski paratamatult mõnevõrra subjektiivsed. Iga lausungi puhul märgiti kuni kaks funktsiooni, kuna koodivahetus täitis sageli rohkem kui ühte funktsiooni. Rohkem kui kahte funktsiooni ühe näite kohta autor ei märkinud, sest rohkemate funktsioonidega lausungite osakaal oli väike. 


\section{Uurimistulemused}

\subsection{Koodivahetuse funktsioonid}

Koodivahetuse sotsiopragmaatiliste funktsioonide alasele kirjandusele ja uurimisandmestikule toetudes selgus, et uuritavas materjalis ilmneb kuus koodivahetuse funktsiooni:

1) semantiline seos (176 lausungit);

2) kvaasitõlge (95 lausungit);

3) sõnaotsing (63 lausungit);

4) keelemäng (6 lausungit);

5) voorudeülene keeleharmoonia (26 lausungit);

6) ekspressiivsus (29 lausungit).

Joonisel 3 on esitatud analüüsitavates lausungites esinenud funktsioonid vestlusosade võrdluses.

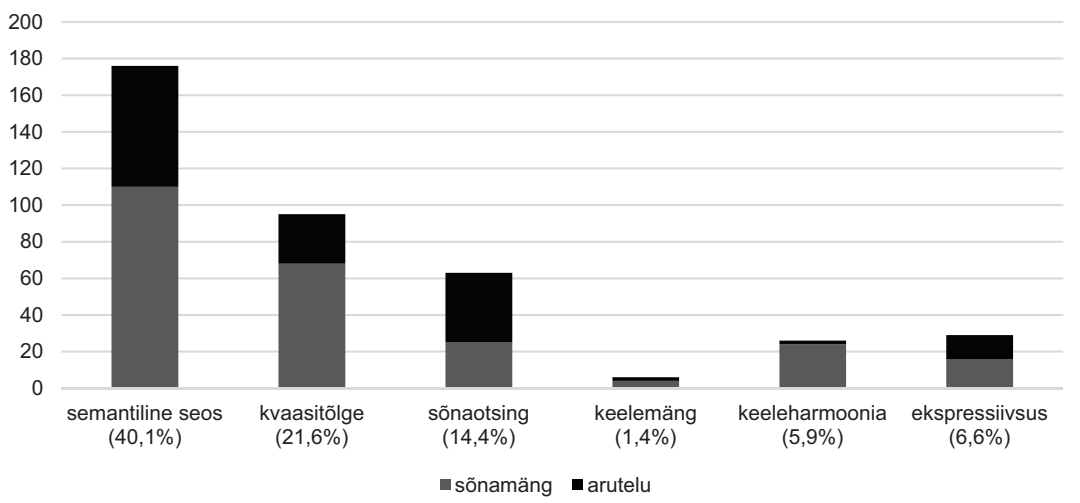

Joonis 3. Koodivahetuse funktsioonid vestluse osades $(n=439)$

Funktsioone ei tohiks vaadelda eraldiseisvatena - pea igast korpuses esinevast lausungist võib välja lugeda vähemalt kahe funktsiooni täitmist ühtaegu. Andmestikus esines lausungeid, kus kasutati noorte omapäraseid keelendeid (nt släng). Seda, kas tegemist oli just identiteedi markeerimisega, oli raske hinnata, mistõttu artiklis seda funktsiooni ei käsitleta (vaatlemata jääb 44 lausungit ehk 10\% uurimisandmestikust, v.a need lausungid, mis olid ka teise funktsiooniga kodeeritud). Järgnevalt on täpsemalt kirjeldatud, milliseid funktsioone täitis uurimisandmestikus esinenud koodivahetus ning kuidas täpsemalt iga funktsiooni piiritleti.

\subsection{Semantiline seos}

Semantiliseks seostamiseks liigitati koodivahetus, kus kõneleja seostas mingit kindlat teemat ühe keelega või vahetas koodi eesmärgiga viidata kindlale teemale. Kokku täitis seda funktsiooni 176 lausungit (40,1\% uurimisandmestikust). Funktsioon põhineb suuresti Aueri (1995: 120) teemavahetuse ja Appeli ja Muyskeni 
(2005: 118-119) referentsiaalsel funktsioonil (vt ka Backus, Verschik 2020). Kui arutlusel oli üks konkreetne teema (või sõna), siis viidati vestluses sellele aeg-ajalt keelt vahetades. Vahel eelistati mõne valdkonna või teema juures kindlaid sõnu teises keeles. Mõlemal juhul oli koodivahetus teemaga semantiliselt seotud, kuid ei kaasnenud konkreetselt teemavahetusega (koodivahetust ilmnes iga teema puhul).

Semantiliselt seotud keel seostus tihti sõnamängus äraarvatava sõnaga, nt (1)-(3).

(1) KJ3: mis aine see on kus on füüsika bioloogia ja keemia KJ5: naturvetenskap [rts 'loodusteaduste õppesuund']

(2) KJ3: näiteks meil on siis geid ja lesbid ja heteroseksu- midagi (.) ma ei tea mis nad on kes nad on (.) ee nagu (...) ee need inimesed kes arvavad KJ5: könsidentitet [rts 'sooline identiteet']

KJ3: ei ei ei

(3) KJ1: nii et röd linje [rts 'punane (metroo)liin'] minu hemmaplan [rts 'kodune peatus'] (.) minu linje [rts '(metroo)liin']

Näited (1) ja (2) järgivad sarnast mustrit: esmalt kirjeldab üks kõneleja laiemalt mõnda teemat, seejärel järgmises voorus ütleb teine kõneleja sõna, mis temal öeldud kirjeldusega seostub. Kuna näited on pärit sõnamängu andmetest, siis on taoline viitamine väga tüüpiline ja ootuspärane käitumine. Mängus tuli ühel keelejuhil kirjeldada ja teis(t)el pakkuda võimalikke sõnu.

Esimeses näites viitab naturvetenskap 'loodusteadus' õppesuunale, kus õpitakse loodusteadusi ehk nii füüsikat, keemiat kui ka bioloogiat. Näites (2) tekib keelejuhil KJ5 seos eelnevalt kirjeldatu ja sõna könsidentitet 'sooidentiteet' vahel. Näide (3) pärineb sõnamängu lindistusest, kus tuli arvata ära fraas Röda linjen, mis on Stockholmi tuntud metrooliini rahvapärane nimetus. Näites on röd linje 'punane (metroo)liin', minu hemmaplan 'kodupeatus' ja minu linje '(metroo)liin' omavahel tähenduslikult seotud, sest KJ1 rõhutab, et see konkreetne metrooliin on liin, millel asub tema kodu.

Vähemal määral tuli ka ette olukordi, kus kood viitas millelegi, mis polnud otseselt seotud etteantud teemaga (4).

(4) KJ5: nagu seal ajalehes nagu mida ma iga päev nagu hommikul loen siis on nagu kirjutatud nagu et oleks nagu see inbördeskrig [rts 'kodusõda'] (.) nagu Rootsi juba (...) et iga pääv on kuskil ee uues kohas mingi ee skjutning [rts 'tulistamine']

KJ3: tulistamine

KJ5: tulistamine ja et (.) nagu kõik see (.) nagu sa ei saa nagu olla (.) ee trygg [rts 'turvaline']

Näites (4) koodivahetuse funktsioonid kattuvad. Ühest küljest ütleb KJ5 rootsikeelseid sõnu puuduliku sõnavara tõttu (vt 4.4), teisest küljest tuleneb koodivahetus aga semantilistest seostest. ${ }^{3}$ See omakorda näitab, et vahetuv kood saab täita mitut funktsiooni. Kui vaadata konteksti, siis esiletoodud sõnad (inbördeskrig 'kodusõda', skjutning 'tulistamine', trygg 'turvaline') on viited ajalehele, mida KJ5 hommikuti loeb ning millele ta lausungit öeldes mõtleb.

3 Selliste andmete puhul on keeruline eristada, kas mõni sõna meenub kergemini ühes või on puudu teises keeles. 


\subsection{Kvaasitõlge}

Kvaasitõlke all mõistetakse mitmekeelse suhtluse viisi, kus kõneleja kordab öeldut teises keeles. Seejuures võidakse korrata mitte üksnes enda, vaid ka teise keelejuhi öeldut. Kvaasitõlge võib toimuda ka eri voorudes. Auer (1995: 120) paigutab kvaasitõlke alla ka sellise koodivahetuse, mille eesmärk oli sõnumit rõhutada või öeldut täpsustada. Siinses uurimuses on öeldu rõhutamist tõlgendatud ekspressiivset funktsiooni täitva koodivahetusena (vt 4.6), sest sõnumi kordamine teises keeles ei tähenda ilmtingimata, et kõneleja soovib seda rõhutada. Nimelt esines Aliast mängides sõnade seletamisel kvaasitõlkeid eelkõige siis, kui öeldut sooviti teha vestluspartneri(te)le selgemaks. Kvaasitõlkeid esines 95 lausungis (21,6\% analüüsitavatest lausungitest).

(5) KJ1: alustame keskkonnaprobleemid (.) jah keskkonnaprobleemid miljö [rts 'keskkond'] rootsi keeles

Näites (5) valib KJ1 aruteluosa vestlusteemaks keskkonnaprobleemid ning kordab vestluse sissejuhatamisel teemat seda osaliselt tõlkides. Kvaasitõlge pole terviklik, sest tõlgitud on vaid eestikeelse liitsõna esimene pool (keskkonnaprobleemi täistõlge rootsi keeles oleks miljöproblem).

Kolme keele mõju tähenduse mõistmisele peegeldub näites (6). KJ3 arutleb selle üle, kuidas öelda högskola 'kõrgkool' eesti keeles. Õige vaste ütleb KJ5 kohe järgmises voorus, selleks on 'kõrgkool', mis on rootsikeelse högskola sõnasõnaline tõlge. Tõenäoliselt tekitab tähendusega segadusi ingliskeelne high school, mis on küll sõna-sõnalt tõlkides sama sõna, aga tähendab hoopis keskkooli.

(6) KJ3: ma ei tea ei aga mis on högskola [rts 'kõrgkool']

KJ5: kõrgkool ma arvan

KJ3: kas see ei ole gümnaasium

KJ4: ei

KJ3: aga mis see on siis

KJ5: keskkool

Üldiselt tõlgiti kas üksiksõnu või terviklausungeid, kuid uurimisandmestikus leidus ka üksiknäide, kus kvaasitõlke funktsiooniga koodivahetus toimus ühes lausungiosas.

(7) KJ5: minu meelest see on nagu inimesest inimesse (.) \$kas saab üldse eesti keeles niimoodi ütleda $\$$

KJ4: \$ma ei tea\$

KJ5: from person till person [rts från person till person '(varieerub) sõltuvalt inimesest']

Näites (7) öeldakse esmalt eesti keelde tõlgitud metafoorne väljend 'sõltuvalt inimesest', seejärel eraldi voorus korratakse väljendi rootsikeelset vastet from person till person. KJ5 kõhkleb eestipärase väljendi korrektsuses ('kas saab üldse eesti keeles niimoodi ütleda'), mistõttu täpsustab ta oma mõtet rootsipärase väljendiga. 


\subsection{Sõnaotsing}

Sõnaotsing tähistab sellise funktsiooniga koodivahetust, kus kõneleja vahetab keelt, sest ta ei tunne konkreetset väljendit või sõna vestluse põhikeeles või tal on mugavam seletada seda teises keeles. Siinses käsitluses on sõnaotsingu funktsiooni märgitud vaid seal, kus vestluses väljaöeldu põhjal saab öelda, et koodivahetus tuleneb just sellest. Sellise funktsiooniga lausungeid oli 63 ehk 14,4\% uurimisandmestikust. Appel ja Muysken (2005: 118-119) kirjeldavad, et kõneleja vahetab koodi põhjusel, et ta ei oska kindlat sõna vastavas keeles või eelistatakse mingi teema puhul üht kindlat keelt. Temaatilist seostamist on siinses artiklis siiski tõlgendatud omaette semantilise seostamise funktsioonina (vt 4.2).

(8) KJ5: ma pean mõtlema kuidas ma ütlen seda (...) alltså det är ju väldigt fritt här i Sverige och det är tack vare den här saken [rts 'samuti siin Rootsis on ju üpris vaba ja see on tänu sellele asjale’] KJ4: demokratik [< rts demokrati 'demokraatia']

(9) KJ3: ma ei kuula üldse muusikat nii tihti ma kuulan podcasts [ingl 'taskuhääling'] (.) ma ei tea mis see eesti keeles on (.) pole õrna aimugi kas Eestis üldse on podcast

Näide (8) ilmestab, kuidas mõnikord oli keelejuhtidel kergem ja mugavam seletada sõna teises keeles. Sõnamängu koostamisel eeldati, et kirjeldamisel kasutatavad katseisikud seda keelt, milles äraarvatav sõna/väljend on esitatud. Siinne näide on aga ainulaadne: äraarvatav sõna on eestikeelne, kuid seda seletatakse rootsi keeles. Kõneleja esmalt mõtleb, kuidas sõna kirjeldada, millele järgneb paus. Sageli näitavad just pikemad pausid keeltevahelisi üleminekuid.

Sõnaotsingu funktsiooni täitvaid lausungeid võib ka lihtsamini ära tunda, näiteks kui keelejuht küsib, kuidas mingi sõna on eesti keeles (9). Võimalik, et sõna podcast on palju rohkem levinud just inglise keeles, sest selle eestikeelne vaste 'taskuhääling' on ka eestlaste seas harjumatu.

\subsection{Voorudeülene keeleharmoonia}

Keeleharmoonia funktsioon on võetud kasutusele Grosjeani (1982: 152) eeskujul, kes kirjutab koodivahetuse esilekutsumisest (ingl triggering) kui funktsioonist. Tähenduselt on voorudeülene keeleharmoonia täpselt sama, mis tema käsitluses koodivahetus, mis on tingitud eelnevalt kasutatud keelest. Koodivahetus toimub andmestikus kahel viisil. Esimesel juhul kasutab kõneleja ühes voorus kahte keelt (alustab ühega, lõpetab teisega) ja järgmine kõneleja jätkab viimase keele kasutamisega. Nõnda toimub koodivahetus kahe kõneleja voorude vahel. Teisel juhul vahetab kõneleja esimeses voorus koodi ning jätkab selle kasutamist teises voorus. Niivõrd konkreetset piiritlemist Grosjean ei kirjelda. Voorudeülese keeleharmooniaga koodivahetust esines 26 lausungis (5,9\% analüüsitavatest lausungitest).

(10) KJ4: teeme KJ5: säger det på ett annat sätt (...) att aa jag jag pallar jag är [rts 'ütleb seda teisiti et ja ma ma viitsin ma olen'] KJ3: ma ei viitsi 
Näites (10) püüab KJ5 seletada sõnamängus sõna 'viitsima' ning on näha, et ta kasutab seletamisel kvaasitõlget. Kaks lausungit on küll sama kõneleja poolt öeldud, kuid kuna need järgnevad üksteisele, siis ta alustab ning jätkab seletamist rootsi keeles. Sellised laused, kus sama kõneleja ütleb mitu lausungit järjest terviklikult rootsi keeles, on vähe.

(11) KJ2: Greta är ute och [rts 'Greta on väljas ja'] KJ1: dremonstrerar [< rts demonstrerar 'protestib']

KJ2: ei teine sõna

KJ1: skrikar [< rts skriker 'karjub'] [hehe]

Näide (11) pärineb vestlusest, kus püüti arvata ära sõna skolstrejk 'kooliprotest'. Öeldes Greta är ute och 'Greta on väljas ja', ootas KJ2, et KJ1 lõpetaks lausungi õige verbiga (ootuspärane olnuks strejkar 'streikima'). Kuna eelnevas voorus öeldud lause on rootsikeelne, siis KJ1 lõpetabki lause ja ütleb demonstrerar 'protestib' (transkribeeritud häälduse järgi kui dremonstrerar). Sõna ebasobivuse tõttu pakub ta lause tervikmõtte lõpetamiseks uue verbi, öeldes seda jällegi rootsi keeles.

\subsection{Ekspressiivsus}

Ekspressiivset funktsiooni täitev koodivahetus väljendab kõneleja emotsiooni, hinnangut või võimendab tema öeldut. 6,6\% uurimisandmestikust ehk 29 lausungit oli ekspressiivse funktsiooniga. Ekspressiivsuse väljatoomine põhineb Grosjeani (1982: 153-154) käsitlusel, mille järgi võib keelejuht koodivahetusega oma sõnumit rõhutada. Rõhutava tooniga koodivahetust leidus sageli kõnelejapoolsetes kommentaarides, näiteks mingi isiku või tegevuse kohta.

(12) KJ2: fuck [ingl 'kurat, persse'] ma ei tea

(13) KJ1: me ei kutsu neid sigadeks KJ2: fucking grisen [ingl 'kuradi', rts 'siga']

(14) KJ2: uuh see oli clean [ingl 'puhas'] (.) see oli (...) najs [< ingl nice 'tore']

Ekspressiivsuse üheks tüüpnäiteks võib pidada ropendamist, mida esines uurimisandmestikus küll väga harva. Näiteks ingliskeelset sõna fuck 'kurat' kasutas vaid üks keelejuht (KJ2), et väljendada frustratsiooni (12) või anda hinnang kaasvestleja sõnale gris 'siga', mida rootsi slängis kasutatakse politseile viitamiseks (13).

Näide (14) väljendab vahetuva koodi abil hinnangut või arvamust. KJ2 kommenteerib momenti mängus, kus sõna arvati ära üheainsa kirjeldava lausega. Ta väljendab rahulolu (najs 'tore') ning rõhutab, et tegemist oli nii-öelda puhta tööga (clean 'puhas'). 


\subsection{Keelemäng}

Keelemängu funktsiooni täidab koodivahetus, kus kõneleja mängib keelega, luues loomingulisi konstruktsioone või põhjustades naljaka olukorra. Seda funktsiooni kohtab ka Aueri (1995: 120) ning Appeli ja Muyskeni (2005: 120) loeteludes (vt ka Verschik 2008: 172-181). Kõnelejad mõtlesid välja uusi sõnu, integreerisid teise keele sõnu põhikeele malli, mängisid hääldusega. Keelemäng kutsus mõnikord esile kaasvestlejate reaktsioone, näiteks hakati naerma või vastupidi, satuti segadusse. Keelemängu leidus uurimisandmestikus kõige vähem, 1,4\% ehk 6 lausungis.

Näited (15) ja (16) pärinevad samast vestlusest, kus keelejuht KJ2 pani kõrvale ühe sõnalipiku, sest ei teadnud sellel olevat sõna.

(15) KJ1: see (.) appi (...) sa ei tea seda sõna eesti keeles onju

KJ2: $\mathrm{mkm}$

KJ1: $\underline{\text { sugu }}$

KJ2: kõ-

KJ1: see on kön [rts 'sugu']

(16) KJ1: \$sa mõtsid sa lugesid eesti keeles köön vää\$

KJ2: \$jaa $\$$ [hehe]

KJ1: \$oi\$ [hehe]

KJ2: \$ma lugesin koon\$

KJ1: see on kön

KJ2: \$åå nej: [rts 'oh ei’]\$

Arutelu käigus selgus, et sõna mitteteadmine oli tingitud sellest, et KJ2 luges seda eestipärase hääldusega. Keelejuht oli eelnenud vestluses eesti keelele ümber lülitunud ega mõelnud enam rootsi keele raamistikus. Seda kinnitas ta hiljem kommenteerides:

(17) KJ2: asi on selles et nii palju seda eesti keeles \$et mu aju nagu arvas et see on eesti keeles\$

Vastav hääldusega mängimine mõjus vestluspartnerile aga humoorikana. Ühtlasi ilmestab näide seda, kuidas ühe keele aktiveeritus mõjutab teise keele mõistmist.

\section{Kokkuvõte}

Artiklis on heidetud esmane pilk rootsieesti noorte koodivahetuse funktsioonidele. Kogutud keeleainestikust tuvastati kuus koodivahetuse funktsiooni: semantiline seos, kvaasitõlge, sõnaotsing, keelemäng, voorudeülene keeleharmoonia ja ekspressiivsus.

Analüüsist selgus, et kõige rohkem vahetati koodi keele semantiliste seoste tõttu. Selle funktsiooni ülekaalu on leitud ka teistes uuringutes (vt osa 2). Semantiline seos näitab, et kõnelejad on harjunud kindlas situatsioonis või kontekstis kasutama ühte keelt, seega võib ühe keele eelistamine teisele olla seotud harjumuse, kasutussageduse või sõnavara puudulikkusega. Näiteks kui kõneleja on harjunud lugema ajalehti rootsi keeles, siis vastavas väljaandes kajastatud uudiseid kommenteerides eelistab ta kasutada rootsikeelseid sõnu. 
Tihti korrati öeldut teises keeles. Kõneleja kordas öeldut selguse mõttes näiteks eeldusel, et öeldu on vestluspartnerile teises keeles arusaadavam. Sõnamängudes toimis kvaasitõlge justkui strateegiana, millega kõnelejad kirjeldasid äraarvatavaid sõnu. Arutelus korrati öeldut teises keeles tihti siis, kui kõnelejal ei õnnestunud oma tervikmõtet edastada vestluse põhikeeles.

Vähemal määral esines keeleharmooniat, kus kõneleja jätkas eelmises voorus kasutatud keelega. Näiteks alustas noor lauset rootsi keeles ning tema vestluskaaslane lõpetas lause samuti rootsi keeles, kuigi põhiline suhtluskeel oli eesti keel. Koodivahetusega väljendati mõnikord mõnd emotsiooni või rõhutati enda öeldut. Siinkohal toimus üleminek tihti inglise keelde, kuigi uurimisandmestikus esines oluliselt rohkem eesti-rootsi kui eesti-inglise koodivahetust. Võimalik, et selline erisus tulenes inglise keele tugevatest emotsioonisõnadest (fuck, oh my god), mis noortele keelejuhtidele võisid olla kättesaadavamad või rohkelt kasutusel. Kõige vähem lausungeid täitis keelemängu funktsiooni. Sellisel juhul toimis mitmekeelsus mängulisena, keelejuhid tegid teise keele kasutusega nalja ning lõid loomingulisi keelendeid.

Kasutatud meetod tingib paratamatult teatud kallutatuse uurimistulemustes. Vestlusringide formaat aitas küll kaasa kahe keele aktiveerimisele, kuid mõjutas ka koodivahetuse toimimisvõimalusi, ilmnevaid funktsioone ja nende sagedusi. Koodivahetuse mustrite tõlgendamisega kaasneb paratamatult vaatleja subjektiivsus. Seetõttu võiks järgmise sammuna uurida rootsieesti teismeliste keelekasutust teiste meetodite (näiteks poolstruktureeritud intervjuu) ja suurema andmestiku abil.

\section{Transkriptsioonimärgid ja lühendid}

\begin{tabular}{|c|c|}
\hline $\mathrm{KJ} 1, \mathrm{KJ} 2, \mathrm{KJ}_{3}, \mathrm{KJ} 4, \mathrm{KJ} 5$ & keelejuhid \\
\hline met- & kõnelemisel pooleli jäetud (katkestatud) sõna \\
\hline nii: & venitatud häälikud \\
\hline (.) & mikropaus (1 sekund või lühem) \\
\hline (...) & pikem paus (üle 1 sekundi) \\
\hline hehe & naer \\
\hline$\$ \ldots . . \$$ & naerva häälega öeldud sõna või lõik \\
\hline [rts (att) gymma 'treenima'] & rootsikeelne tõlge \\
\hline [ingl penthouse 'katusekorter'] & ingliskeelne tõlge \\
\hline \#...\# & pikema võõrkeelse lausungi tõlge, mis on eraldi real \\
\hline skogen & koodivahetus \\
\hline ma ei tea & koodivahetusega seotud lausung(iosa) \\
\hline ingl & inglise keel \\
\hline & rootsi keel \\
\hline
\end{tabular}

\section{Viidatud kirjandus}

Allwright, Dick 2014. Observation in the Language Classroom. London-New York: Routledge. https://doi.org/10.4324/9781315835907

Alumäe, Tanel; Tilk, Ottokar; Asadullah 2018. Advanced Rich Transcription System for Estonian Speech. - Kadri Muischnek, Kaili Müürisep (Eds.), Human Language Technologies - The Baltic Perspective. Proceedings of the Eighth International Conference. Frontiers in Artificial Intelligence and Applications 307. IOS Press, 1-8. https://doi. org/10.3233/978-1-61499-912-6-1 
Appel, René; Muysken, Pieter 2005. Language Contact and Bilingualism. Amsterdam: Amsterdam University Press.

Auer, Peter 1995. The pragmatics of code-switching: A sequential approach. - Lesley Milroy, Pieter Muysken (Eds.), One Speaker, Two Languages: Cross-Disciplinary Perspectives on Code-Switching. Cambridge: Cambridge University Press, 115-135. https://doi. org/10.1017/CBO9780511620867.006

Auer, Peter 1999. From code-switching via language mixing to fused lects: Toward a dynamic typology of bilingual speech. - International Journal of Bilingualism, 3 (4), 309-332. https://doi.org/10.1177/13670069990030040101

Backus, Ad, Anna Verschik 2020. Bilingual language use. - Pieter Muysken, Ad Backus, Suzanne Aalberse (Eds.), Heritage Languages: A Language Contact Approach. Amsterdam: John Benjamins, 67-86. https://doi.org/10.1075/sibil.58

Becker, Kara 2013. The sociolinguistic interview. - Christine Mallinson, Gerard Van Herk, Becky Childs (Eds.), Data Collection in Sociolinguistics: Methods and Applications. New York: Routledge, 91-100.

Gardner-Chloros, Penelope 2005. Code-Switching. Cambridge: Cambridge University Press.

Grosjean, François 1982. Life with Two Languages: An Introduction to Bilingualism. Cambridge, Mass: Harvard University Press. https://doi.org/10.1017/CBO9780511609787

Gumperz, John Joseph 1982. Discourse Strategies. Cambridge: Cambridge University Press. https://doi.org/10.1017/CBO9780511611834

Hein, Kadri 2014. Switching between Estonian Sign Language and Spoken Estonian in a school environment. - Eesti Rakenduslingvistika Ühingu aastaraamat, 10, 91-106. https://doi.org/10.5128/ERYa10.06

Hoffman, Michael 2014. Sociolinguistic interviews. - Janet Holmes, Kirk Hazen (Eds.), Research Methods in Sociolinguistics: A Practical Guide 1. Hoboken, New Jersey: John Wiley \& Sons, 25-41.

Joenurma, Elina 2016. Eesti-läti koodikopeerimine: adaptsioon ja impositsioon ['EstonianLatvian code-copying: adoption and imposition']. - Philologica Estonica Tallinnensis, 1, 62-77. https://doi.org/10.22601/PET.2016.01.05

Johanson, Lars 2002. Do languages die of 'structuritis'? On the role of code-copying in language endangerment. - Italian Journal of Linguistics, 14, 249-270.

Keevallik, Leelo 2006. Pragmaatiliste partiklite laenutüübid rootsieesti keeles ['The types of borrowed pragmatic particles in Swedish Estonian']. - Helen Koks, Jan Rahman (Toim.), Mitmekeelsus ja keelevahetus läänemeresoome piirkonnas. Võru instituudi toimetised 18. Võru: Võro Instituut, 116-133.

Keevallik, Leelo 2010. Everyday construction of identity in the Estonian refugee community in Sweden. - Journal of Baltic Studies, 41 (2), 177-200. https://doi. org/10.1080/01629771003731705

Kiviloog, Jaak 1983. Eesti laste nimisõnavarast Rootsis ['Names of Estonian children in Sweden']. - Mana, 52, 22-25.

Korkus, Mari-Liis 2020. Miks nad blandavad? Koodivahetuse funktsioonidest viie rootsieesti kakskeelse teismelise näitel ['Functions of Code-switching in the Speech of Five Swedish-Estonian Teenagers']. Magistritöö. Tartu: Tartu Ülikool. http://hdl.handle. net/10062/68554

Kumer-Haukanõmm, Kaja; Telve, Keiu 2017. Eestlased maailmas ['Estonians in the world']. Tiit Tammaru, Raul Eamets, Kristina Kallas (Toim.), Eesti inimarengu aruanne 2016/2017: Eesti Rändeajastul. Tallinn: Eesti Koostöö Kogu, 74-81. https://2017. inimareng.ee/valjapoole-avatud-eesti/eestlased-maailmas/ (7.10.2020).

Laagus, Aino; Klaas, Birute; Allik, Mari 2004. Lõuna-Rootsi eestlased ja nende keel. Valimik intervjuusid ['Estonians of Southern Sweden and their Language: Interviews']. Tartu Ülikooli eesti keele (võõrkeelena) õppetooli toimetised 4. Tartu: Tartu Ülikooli Kirjastus. 
Myers-Scotton, Carol 1997. Duelling Languages: Grammatical Structure in Codeswitching. Oxford: Clarendon Press.

Myers-Scotton, Carol 2006. Multiple Voices: An Introduction to Bilingualism. Oxford: Blackwell Publishing.

Nemvalts, Peep 1998. Kas väliseesti keeles on märgata süntaktilist omapära? ['Are there any syntactic peculiarities in Estonian language abroad?'] - Liina Lindström (Toim.), Väliseestlaste keelest. Tartu Ülikooli eesti keele õppetooli toimetised 9. Tartu: Tartu Ülikooli Kirjastus, 55-66.

Oksaar, Els 1970. Kaksikkeelsusest eesti ja rootsi keele tagapõhjal ['On Estonian-Swedish Bilingualism']. Stockholm: Stockholmi Eesti Algkool.

Praakli, Kristiina 2016. Eesti-soome koodivahetuse mitu nägu Facebooki vestluste näitel ['The multiple faces of Estonian-Finnish code-switching seen from Facebook conversations']. - Philologia Estonica Tallinnensis, 5, 126-151. https://doi.org/10.22601/ PET.2016.01.08

Raag, Raimo 1982. Lexical Characteristics in Swedish Estonian. Uppsala: Uppsala University.

Raag, Raimo 2010. Eestlased ja eesti keel Rootsis ['Estonians and the Estonian language in Sweden']. - Kristiina Praakli, Jüri Viikberg (Toim.), Eestlased ja eesti keel välismaal. Tallinn: Eesti Keele Sihtasutus, 385-432.

Zabrodskaja, Anastassia 2006. Vene-eesti koodivahetuse funktsioonid Kohtla-Järve venekeelsete laste vestluses ['The conversational functions of Russian-Estonian codeswitching among Russian-speaking children in Kohtla-Järve']. - Eesti Rakenduslingvistika Ühingu aastaraamat, 2, 231-251. https://doi.org/10.5128/ERYa2.16

Thomason, Sarah Grey 2001. Language Contact: An Introduction. Washington: Georgetown University Press.

Thomason, Sarah Grey; Kaufman, Terence 1991. Language Contact, Creolization and Genetic Linguistics. Berkeley: University of California Press.

Valk, Aune; Karu, Kristel 2002. Eesti identiteet Eestis ja Rootsis ['Estonian identity in Estonia and in Sweden']. - Aune Valk (Toim.), Eesti ja eestlased võrdlevas perspektiivis. Kultuuridevahelisi uurimusi 20. sajandi lõpust. Tartu: Tartu Ülikooli Kirjastus, 125-141.

Verschik, Anna 2004. Koodivahetus meil ja mujal ['Code-switching home and away']. - Keel ja Kirjandus, 1, 25-45.

Verschik, Anna 2008. Emerging Bilingual Speech: From Monolingualism to Code-Copying. London: Continuum publishers.

Verschik, Anna 2010. Keelekontaktid ja kontaktidest johtuvad keelemuutused ['Language contacts and contact-induced language change']. - Jüri Viikberg (Toim.), Välis-eesti keelevariandid. Tallinn: Eesti Keele Sihtasutus, 143-173.

Verschik, Anna 2019. English-Estonian code-copying in blogs: Combining a contact linguistic and cognitive approach. - Eline Zemmer, Ad Backus, Esme Winter-Froemel (Eds.), Cognitive Contact Linguistics: Placing Usage, Meaning and Mind at the Core of Contact-Induced Variation and Change. Berlin-Boston: De Gruyter Mouton, 51-80. https://doi.org/10.1515/9783110619430-003

Vihman, Virve-Anneli 2018. Language interaction in emergent grammars: Morphology and word order in bilingual children's code-switching. - Languages, 3 (40), 1-23. https:// doi.org/10.3390/languages3040040

\section{Võrguviited}

ELAN: Annotation tool for audio and video recordings. Nijmegen: Max Planck Institute for Psycholinguistics, The Language Archive. https://archive.mpi.nl/tla/elan (9.10.2020). SCB = Statistika centralbyrån. https://www.scb.se/ (20.10.2020).

SEKK = Tartu Ülikooli suulise ja arvutisuhtluse labori suulise eesti keele korpus. http://www. cl.ut.ee/suuline1/suulisekorpus/ (11.10.2020). 


\title{
A SOCIOPRAGMATIC APPROACH TO CODE-SWITCHING: A CASE STUDY OF SWEDISH-ESTONIAN TEENAGERS
}

\author{
Mari-Liis Korkus
}

University of Tartu

The aim of this article is to give an overview of code-switching functions in the spoken conversations of five Swedish-Estonian teenagers. Generally, code-switching research has been approached in two ways: grammatically and sociopragmatically. The latter was the favoured approach for this paper since it helped distinguish code-switching patterns and the functions which they represent. These functions, on the other hand, give an insight into why the speaker switches between two or more languages.

Data was collected from five young informants, between the ages of $15^{-17}$ years, all of whom spoke both Estonian and Swedish fluently. Given the speakers' age, the analysis also covered the usage of English. The informants were recorded in the form of conversation groups - a less common method for researching codeswitching. A total of 4 hours of speech was recorded, out of which approximately $24.6 \%$ (439 utterances) contained switches between languages.

All in all, six code-switching functions were found to systematically appear in the utterances. These include semantic specifications, quasi-translations, vocabulary limitations, expressiveness, word play and cross-utterance language harmony. The results were somewhat biased, which is why, for future notice, it would be suggested to approach different informants with a different method.

Keywords: multilingualism, code-switching, lexicon, Estonian, Swedish, English

Mari-Liis Korkus (Tartu Ülikool) uurimisteemaks on rootsieesti teismeliste suuline keelekasutus. Jakobi 2, IV korrus, 51005 Tartu, Estonia

mari-liis.korkus@ut.ee 